\title{
Pricing Linkages Between Added Value Levels Of The Beef Industry: A Systems Approach
}

Jack Trierweiler, (E-mail: Jack_Trierweiler@sdstate.edu), South Dakota State University

\begin{abstract}
Agricultural commodities, and in particular the livestock industry, experiences cycles in prices, demand, and supply conditions. Large variations can result from a variety of factors which influence the regularity, magnitude, and the severity of the cycles. In the last few years the U.S. Livestock industry has suffered through hard financial times. Grass roots organizations such as WORC have accused the packers for using their economic power gained from concentration and the use of captive supplies for low prices at the slaughter and cow-calf levels. To compound the issue $I B P$, the largest beef packer, with 33 percent of the beef kill is for sale and has been bid on by other packers, potentially concentrating the industry more and reducing the number of bidders for slaughter cattle. The article found that the inefficiencies and price distortion in the value system were not at the packer level, but rather the retail level and between the feedlot level and the cowcalf levels. Because of changing marketing arrangements, price discovery issues in the concentrated markets needs to be resolved before suspicion will disappear.
\end{abstract}

\section{Introduction}

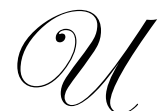

nited States Family farmers and ranchers have experienced troubling financial hard times, while the rest of the U.S. economy has enjoying relatively sustained economic growth and prosperity. Less and less of the food dollars makes their way back to the basic production level. Family farms point to the increased concentration at the processing and packer levels as the crux of their income problems, and accuse these" middlemen" of draining excess profits from their operations.

Splinter organizations such as No Bull (the Cattlemen's Legal Fund) and R-Calf (Rancher-Cattlemen Action Legal Fund) have grabbed media headlines by assertions that low-farm prices for beef and pork are the result of packer and retailers greed. WORC (Western Organization of Resource Council), a self described federation of grass roots organizations, maintains that packers are using economic power (concentration) and anti-competitive activities (captive supplies) to force down commodity prices to independent farmers and ranchers. They maintain, that these same packers and processors (Smithfield Foods, Conagra, Tyson, Archer Daniels Midlands, Cargill, Excel, IBP, Farmland) are transnational corporations spreading their power worldwide to get control of the world meat trade, and specifically the beef industry. That these TNC's are using political clout obtained by being the leading contributors to campaigns of politicians running for congressional offices (according to the Center for Public Integrity). They maintain that these same politicians are in positions of oversight on committees set up to regulate a fair playing field in the market place.

Farmers and ranchers have been saying for years, that many agricultural commodity markets do not offer honest price discovery. They maintain " that five guys on the telephone is not a market"(Guebert, 2000). It is not a market when three beef packers, IBP, Cargill, and ConAgra control 76 percent of the US cattle slaughter. It is not a market when two grain merchandisers, Cargill and Archer Daniels Midland (ADM), own 80 percent of all sites for delivery of CBOT corn and soybeans contracts. It is not a market when 50 percent of all US grain exports are handled by Cargill and ADM. It is not a market when Smithfield, IBP, ConAgra, Cargill, And Farmland control 64 percent of the hog kill. Many agriculture producers argue that they don't sell into markets, they sell to cartels and these 
are not functioning markets. The problem is magnified when the same dominant players hold strong positions in each of the market segments.

To compound the issue further, on November 13, 2000 Smithfield Foods announced an offer to buy IBP for $\$ 3.7$ billion. Smithfield, the number one pork packer with 18.2 percent of the daily kill offers to buy IBP, the largest beef packer with 33 percent of the beef kill, and second largest hog killer with 17.3 percent of the daily kill. Smithfield's slaughter capacity is focused in the Mid-Atlantic with only two plants in the Midwest. In contrast, the bulk of IBP's hog processing is in the Midwest. The two firms differ in their approach to acquiring hogs. Smithfield owns a majority of the hogs it slaughters with a reported goal of becoming 100 percent vertically integrated. IBP purchases its hogs through marketing contracts and on the open market.

OCM (Organization for Competitive Markets) immediately called for a two-year moratorium on meat packer/processor mergers, alleging that the merger would further concentrate the meat packing sector and remove the largest player (IBP) in the cash market for hogs. It would hasten the vertical integration of the hog and cattle sectors. It would reduce capacity in the slaughter sector, and increase Smithfield's ability to manipulate prices, and further create new barriers to entry in wholesale to retail meat trade. If the merger materializes, industry analysts argue that Smithfield will sell off the cattle slaughter capacity, likely to one or more of the remaining two rivals, further concentrating the livestock packing/processing industry.

On January 2, 2001, Tyson Foods, Inc., announced a deal to purchase IBP after a heated bidding war with Smithfield Foods. The deal would merge the country's largest poultry producer and processor with the country's largest processor of red meat. On March 29, Tyson announced plans to back out of the agreement, alleging IBP accounting irregularities. IBP sued Tyson to require it to complete the agreement. On June 15, 2001 A Delaware Judge orders Tyson to complete the acquisition of IBP. If Tyson completes the acquisition, the new mega-meat company would control 30 percent of the beef market, 33 percent of the chicken market, and 18 percent of the pork market.

\section{Price Discovery}

In the 50s, 60s, and 70s the vast majority of the cattle and calves were sold in public markets and the prices for various classes, weights, grades, and etc. were reported by the livestock news and the USDA. Because of the numbers bought, sold, and reported, especially in markets like Omaha, Kansas City, Denver, and Fort Worth, the prices were readily accepted by most in the industry as reliable signals of the prevailing supply and demand conditions, or at least the best available.

Many studies of the livestock industry (Mighell and Jones, 1963; Trierweiler and Hassler, 1971; Purcell, 1973; Paul, 1974; and Breimyer, 1976) were warning that the market-price system was not nor could not coordinate the vertically related stages of production and marketing. What was being produced was not responsive to changing consumer preferences, thus threatening the economic viability of the entire system. In the 1970s most fed cattle were priced on a live weight, cash market basis. Variations in transaction price were the result of carcass prices, live cattle future market prices, cattle quality (including sex, weight, quality grade, and yield grade), sale lot size, number of days between purchase and delivery, number of buyers bidding, individual packing plants, time of year, and region of the country (Ward, 1981).

Many things have changed since the 1970s. Transaction prices in a price model today would include more dressed beef prices and dressed weight and grade prices (formula or grid prices) and more forward contract prices. Pricing, done on an individual animal basis, would include the following variables in addition to the 1970s list: boxed beef cutout values (instead of carcass beef price), individual feedlots, day of the week, and extent and type of captive supplies (Ward, 1992; Ward, Koontz, and Schroeder, 1996). Packers point out that individual pricing of animal using formulas and grids prices cattle at values the consumer places on these products and guarantees a future flow of these qualities (Purcell, 1997). Pricing would not be on a bid and ask basis.

Price discovery has become a major concern to cattle feeders and others in the 90s. Cattle feeders in the past tended to market and packers purchase whole show lists of fed cattle at a single price. Consequently, better and 
poorer cattle are priced the same, despite significantly differences in quality and yield. As packers attempt to move to case ready and branded beef programs, more consistency is needed and there are clear reasons to pay different prices for different quality cattle. Formula pricing and/or grid pricing have rapidly replaced the average pricing methods in the fed cattle market. Unfortunately, the shear volume needs by packers to keep costs low and competitive have resulted in increased use of captive supplies procurement methods. The absolute amount of fed cattle handled by just three large packers plus the concerns related to packer concentration, has led producers to question the market power in fed cattle procurement.

From a packer's point of view, gains from vertical coordination from a daily flow of cattle into their plant near their optimal processing capacity, will allow them to process cattle $\$ 2$ to $\$ 5$ per head cheaper than is currently the norm for the industry. USDA data show that daily slaughter rates vary in beef plants by about 15 percent from day to day. Packers can cut costs significantly by running within 5 percent of their optimal capacity rate. Five percent under utilization of a plant costs the packer about $\$ 1 /$ head. Ten percent under utilization cost about $\$ 2 /$ head and 14 percent under utilization costs about $\$ 5 /$ head (Anderson and Trapp, 1999).

As a result, today's cash markets volumes are so thin they are not creditable within the industry as a price discovery mechanism. Cattle that are still sold on a live weight basis are generally priced at the lowest level for their quality grade and dressing percentage (Ward, Feuz, Schroeder, 1999). Therefore prices reported by the USDA and market news services, represent the lowest prices for each livestock category. Many livestock analyst reluctantly accept this process as only a proxy for true price discovery. ${ }^{\mathrm{i}}$

\section{Market Power Concerns}

In October 1996, WORC filled a petition with the Secretary of Agriculture to issue rules that would prohibit packers from procuring cattle for slaughter through the use of forward contract. To be legal, the contract must contain a firm base price that can be equated to a fixed dollar amount on the day the contract is signed; and the forward contract is offered or bid in an open, public manner. Second, packers would be prohibited from owning and feeding cattle, unless the cattle are sold for slaughter in an open, public market.

The petition further asked that packers be prohibited from using " formula" or "basis' pricing on forward contracts. This would preclude the relating of price at delivery to an observable cash price series (the formulapricing approach) or to a futures contract price (the basis approach). The procedures for pricing and price discovery in the petition would allow forward cash contracting, but only if the contract provides for a firm and specific base price when the contract is signed. All contracts would have to be offered on bid in an open, public manner and the WORC indicated that such an approach would meet the entire industry's need for timely, accurate, value-based, and competitive price discovery.

The WORC petition came subsequent to, and was used in support parts of the report from a USDA advisory committee formed by the Secretary of Agriculture to look at the economic impacts of concentration in agriculture. That committee discussed problems they felt were indicative of increasingly concentrated and industrialized agricultural industries. One specific problem was attributed to the increased use of formula pricing arrangements. Their concern, and the concern echoed by the WORC, was that the base price being used in the formula arrangements was and could be manipulated by packers in a highly concentrated marketplace.

\section{Industry Model Development}

Given the above industry environment, a model was developed that could be used to examine the beef cattle industry. A model that would incorporate the various distinct sectors of the beef industry, and the factors in time, form, and space that most affected the industry's behavior. The model definition started with the premise that the model boundaries should contain the four major sub sectors of the industry; the cow-calf sector, the feedlot sector, the packer-fabrication sector, and the retail sector. Import/export components directly affect the first three sub sectors, and indirectly the retail sector.

Livestock and meat statistics from USDA's "Redbook", an extensive data set that contained price, produc- 
tion and disposition data from farm and ranch production to retail marketing and consumer consumption patterns for beef, pork, poultry and lamb was downloaded from the Economic Research Service website. Additional data on income, price-level indices and labor statistics were downloaded from the Bureau of Labor Statistics website and U.S. Census data.

The second step was to develop causal loop models to identify the elements, their interconnections, and feedback loops for each of the four sub sectors. USDA commodity experts, feedlot operators, and meat marketing experts helped with identifying the causal loops. After development of the causal loop diagrams, the problem identification was limited to the time dimensions, and ignored at least at the outset the form and spatial aspects of the beef sector.

Third, a systems dynamics simulation model of the beef sector was developed using Powersim ${ }^{\mathrm{TM}}$, from the causal loop models of the beef industry. For purpose of analysis and verification of the model, beef prices at Omaha for 1100-1300 pound choice steers and heifers was chosen as the key indicator variable. Choice slaughter prices has traditionally been the key incentive or decision variable for the organization of production at the cow-calf and feedlot levels, and prices at the box and retail level are highly correlated to choice slaughter prices.

Fourth, an evaluation of the price structure relationships of the beef industry was performed in order to delineate areas of inefficient performance. Special attention was given to the time and form relationships from primary production at the farm or ranch level, to the retail level. Primary concern was presentation and evaluation of statistical and economic results to ascertain critical inefficient performance conditions in the industry. The analysis assumed that prices at retail were accurate representations of consumers' revealed preferences, and did not directly estimate demand functions for retail beef consumption. Recent measurements of retail demand for beef and other meats are well documented (Purcell, 1999), and go beyond the scope of this study.

\section{Price Linkages Between Value-added Sectors}

The overall objective of this section is to evaluate the linkages between value-added sectors of the beef industry. The purpose of the evaluation is to delineate areas of inefficient performance that may be the result from anti competitive behavior or industry concentration In the systems model special attention is given to the time and form relationships from the value added sectors from primary production at the farm or ranch level to the feedlot level, to the packer/fabricator level, to the retail level. Lengthy or elaborate discussion of theoretical estimation is omitted. Primary concern is presentation and evaluation of the price linkages between value added levels to ascertain critical inefficient performance conditions in the industry.

This analysis will assume that prices at retail are accurate representations of consumers' revealed preferences. The systems model uses Purcell's demand functions for the retail level (Purcell, 1999). Between level linkages are based on relationships estimated in earlier studies (Trierweiler, 2001)

\section{Linkages Between Retail and Packer/Fabricator Levels}

Theoretically, in a competitive environment, the price differential between retail and box beef prices should reflect the cost of the added value going from the boxed primal cuts to the case ready form. This would include the cost of further processing the boxes for the retail cases, storage, delivery, cutting and trimming waste, advertising fixed store charges, and any other cost associated with marketing the product at retail, plus normal profit.

The analysis uses data on box and retail prices series from 1985 to 2000 , where box prices are defined as wholesale boxed cut-out values of choice 2-3 grade 550-700 lb. carcasses in cents per pound, and retail prices defined as choice grade in cents per pound converted to box equivalent prices for ease of comparison. Again, if the price system is working efficiently linking the value added sectors (in other words a competitive environment), the difference between the two price series should be minimal, because the cost of the value added components have already been accounted for in the simulation conversion. 


\section{Box Beef Prices Estimated from Retail Prices}

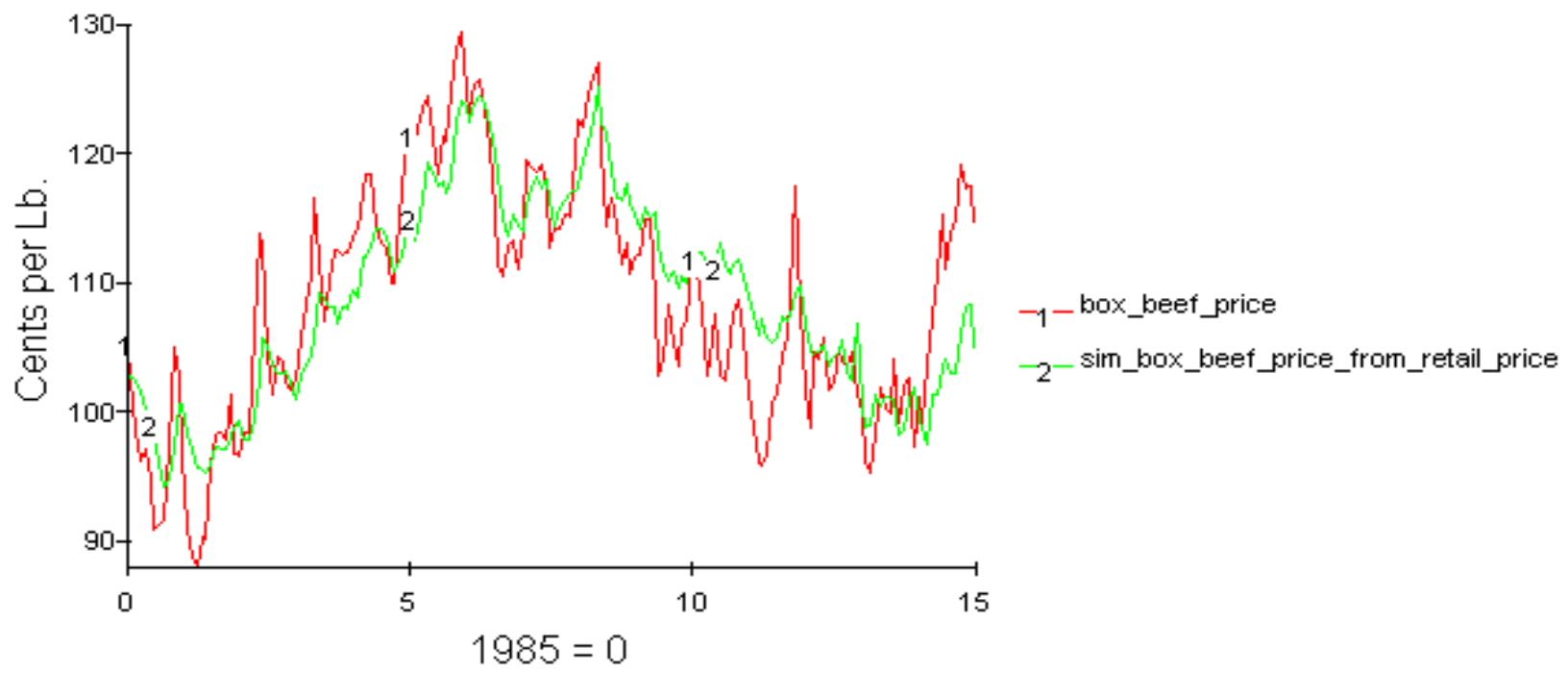

Exhibit 1. Box Beef Prices Equivalents Converted from Retail Added Value Component Costs

The comparison between the two price levels suggests poor price performance in the pricing of product between the two the two value added levels, particularly during downturns in box prices that result from oversupply conditions in the supply chain (exhibit 1). Examining the price differential in exhibit 2, plus as minus price differentials exits as great as 10 cents per pound. Negative price differentials occur during upturns in box prices and positive price differentials during downturns in the price cycles. This can be attributed to the retailer's reluctance to adjust prices (particularly down) to reflect supply conditions in the supply chain. Retail price policy in the grocery business has been to keep prices as stable as possible. The results have generally been that prices to ratchet up with cost increases, but not down with decreases in costs. This retail price strategy, while benefiting the retailer, has resulted in poor price performance further down the supply chain. Furthermore, the price strategy only lengthens the time necessary to clear out the over supply conditions in the supply chain.

\section{Box Beef Price Differentials}

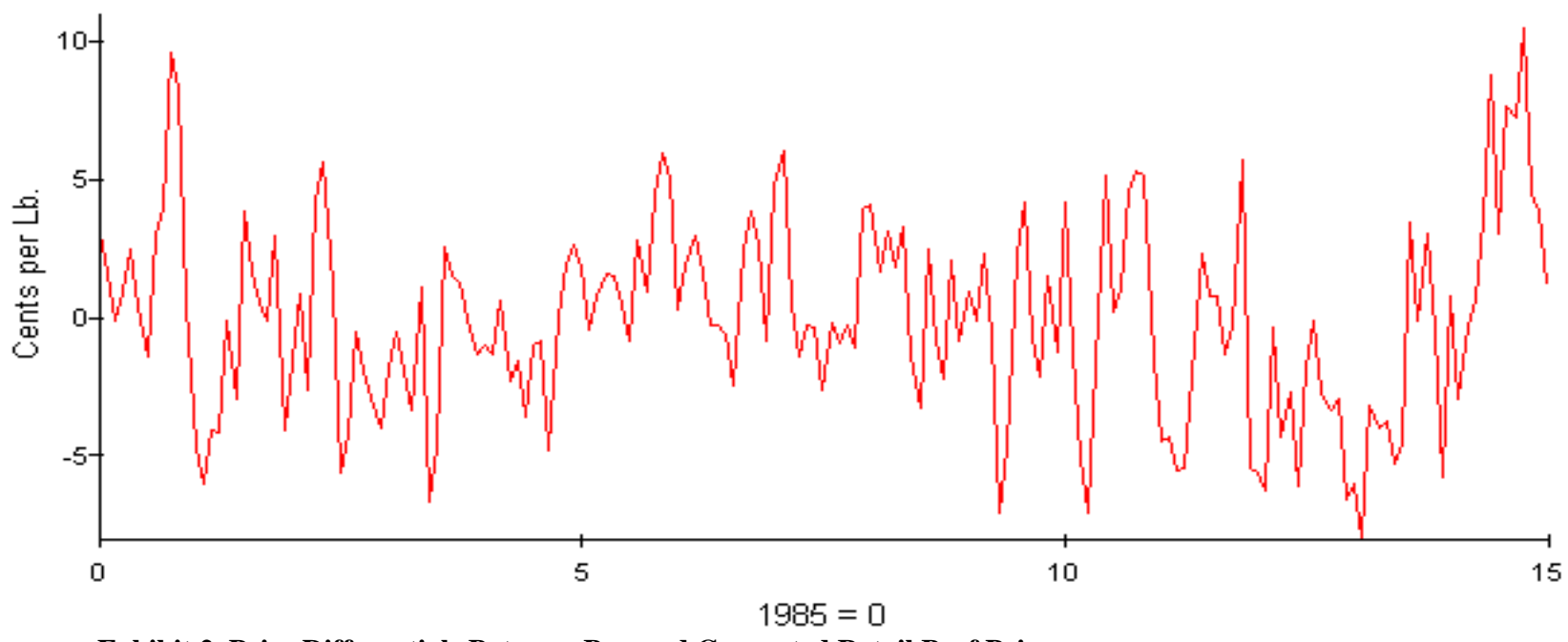

Exhibit 2. Price Differentials Between Box and Converted Retail Beef Prices 


\section{Linkages Between The Feedlot and Packer/Fabricator Level.}

An evaluation of the feedlot to packer/fabricator value added level requires a comparison of the prices of converted box beef and the prices received for slaughter animal at the farm gate. Boxed beef prices are defined identical to the previous analysis except the box beef prices are now converted to the slaughter equivalent prices by accounting for changes in yield (approximately 52 percent of live animal equivalent), the value of salvaged by product(offal , hide, and other by products), the costs of marketing, fixed plant charges, labor , transportation, and normal profits. Slaughter prices are those of choice steers, 1100-1300 pounds sold direct in Nebraska in dollars per hundredweight.

A visual inspection of exhibits 3and4 would suggest the linkages between the two value added levels was reasonably good, indicating relatively good price performance between the two levels. The price linkages at least during this fifteen-year time period were reasonably efficient to further suggest that a sufficient amount of competition exits to discipline this highly concentrated industry and limit excess profits. Further, the evidence would suggest that the packer/fabricator is not the villain causing the income problems of beef producers at the farm and ranch level.

\section{Slaughter Prices and Simulated Slaughter Prices}

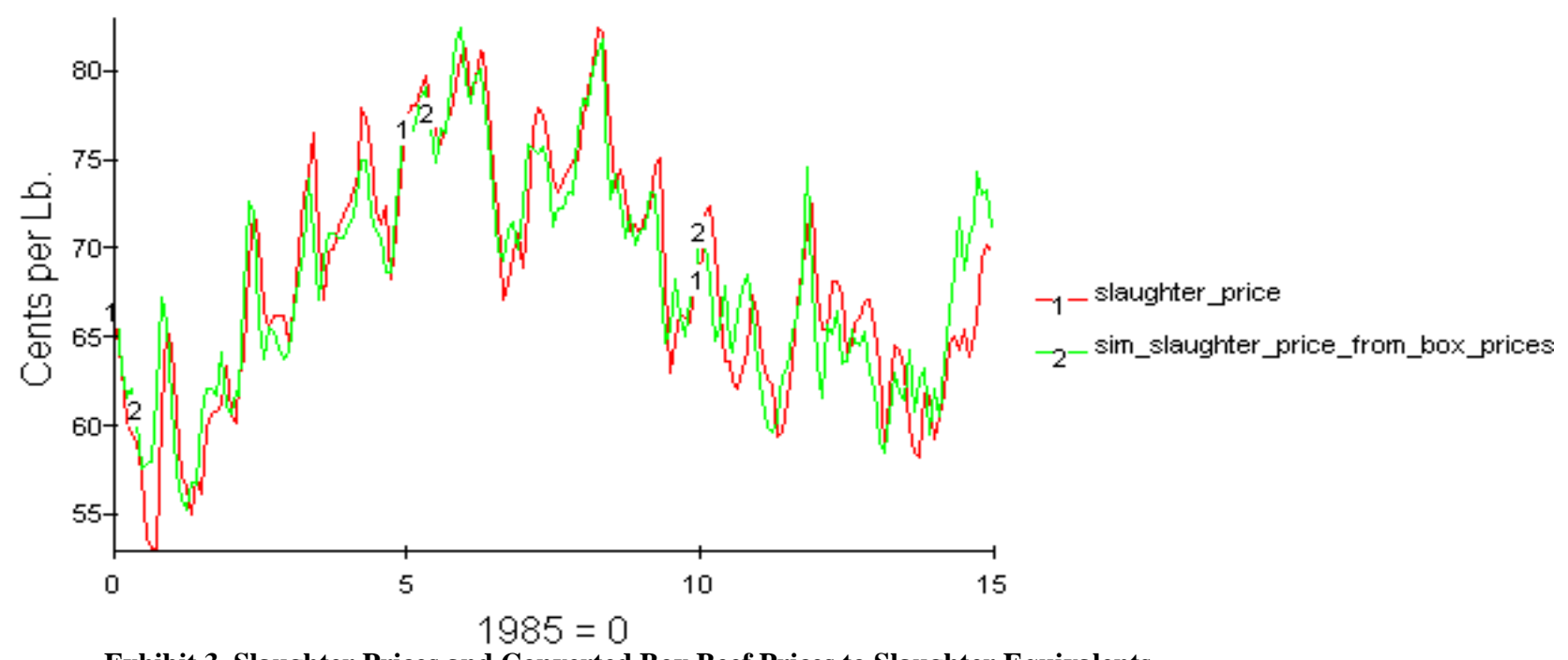

Exhibit 3. Slaughter Prices and Converted Box Beef Prices to Slaughter Equivalents.

\section{Slaughter to Ranch Level}

An evaluation of the slaughter to feeder price linkages requires an analysis of the prices paid for feeder animals, and their eventual slaughter price. The analysis requires lagging the price of feeder animals equivalent to a period of time necessary to fatten the animals from a feeder to slaughter weight. Since the production period typically requires about ten months on the average to take a feeder animal from 650 pounds to slaughter weight, slaughter prices were lagged ten months for the analysis. The price of 600-650 pound feeder steers in Oklahoma in dollars per hundred weight lagged ten months was used for the price of feeder cattle. Again, the price of 1100-1300 pound choice slaughter steers sold direct in Nebraska was chosen as the slaughter price. Slaughter prices were converted similarly to the previous analysis by accounting for all the value added cost and a normal profit. 


\section{Slaughter Price Differentials}

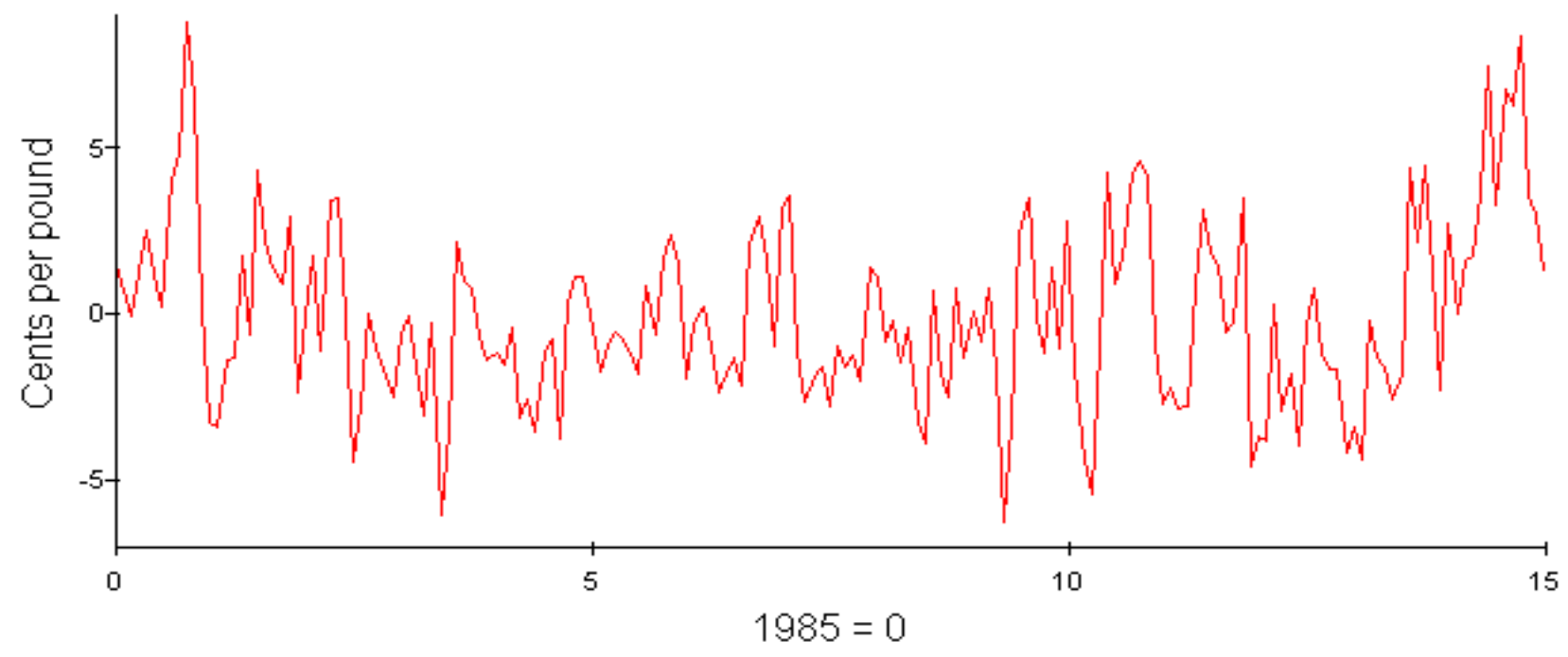

Exhibit 4. Price Differentials Between Slaughter and Converted Box Beef Prices

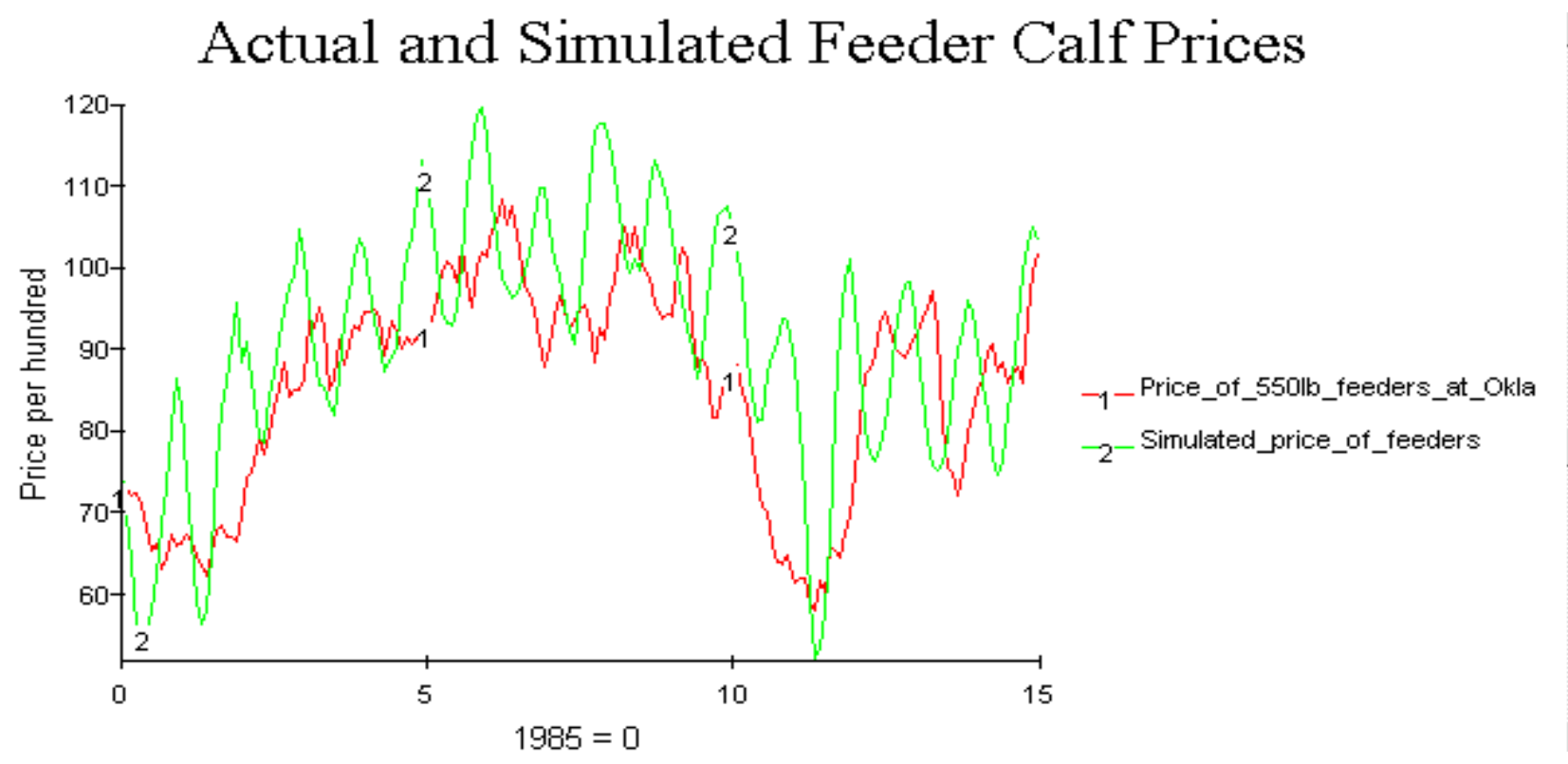

Exhibit 5. Feeder Calf Prices and Converted Slaughter to Feeder Prices by Value Added Costs 


\section{Feeder Calf Price Differentials}

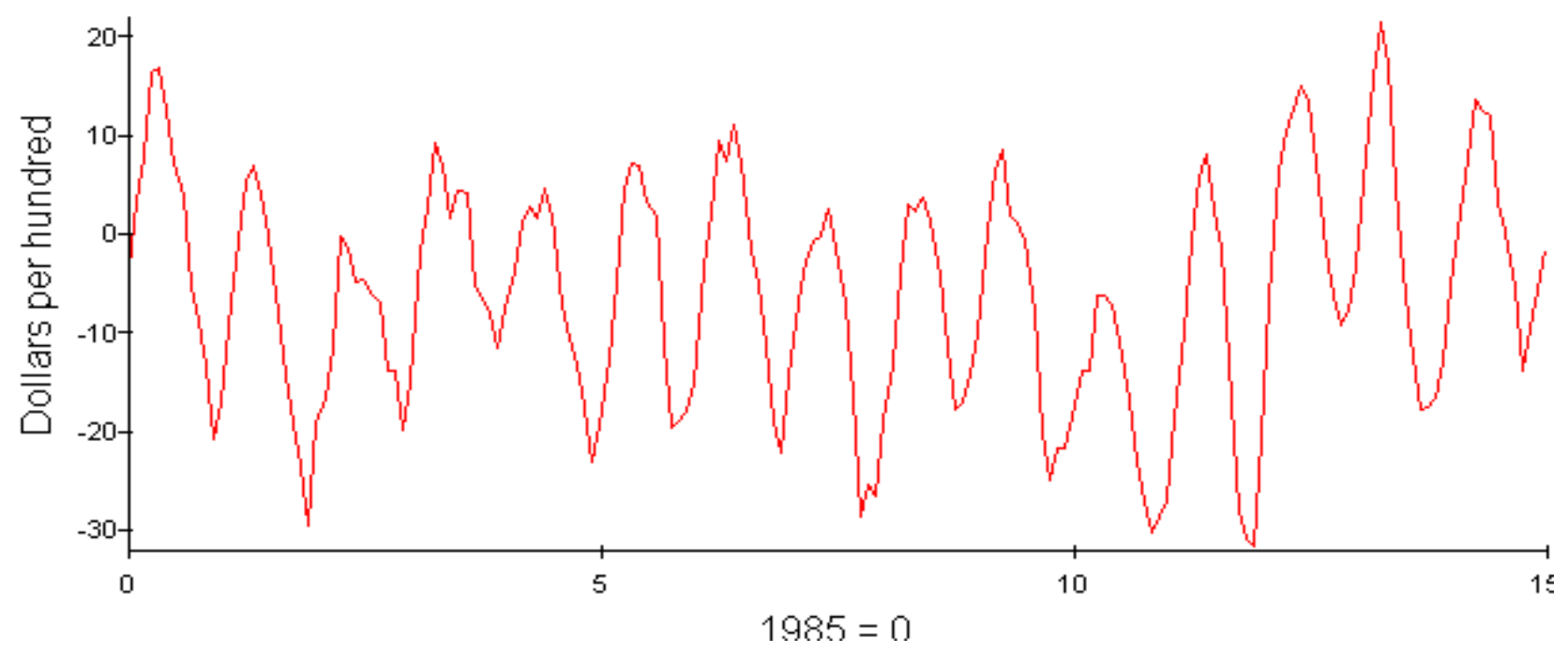

Exhibit 6. Price Differentials for Feeder Cattle in Dollars Per Hundred Weight.

An examination of exhibit 5 and 6clearly point to a price system that has performed extremely inefficient. The price system performs dysfunctional in its dual roles first in pricing the added value of cattle coming from the primary producer at he cow-calf or ranch level; and secondly, sending the appropriate signals for the organization of future production to the primary producer. It should not be a surprise then that ranchers periods of time of extreme income instability when the price signals from the market are this confused.

Exhibit 6 shows price differentials above and/or below zero as 30 cents, with the bulk of these on the negative side. Considerable annual variation occurs in any year further confusing the added value linkages for this level.

\section{Implications}

The linkages in the proceeding analysis reflect competitive forces, which produce efficient performance between the slaughter and the wholesale level. Poor price performance was found at the retail levels and between the ranch and feedlot levels. Results showed that retail prices only weakly responded to supply conditions at the slaughter-wholesale levels, thus magnifying and lengthening distorted supply/demand imbalances further down the supply chain where producers are price takers.

Weak price performance was also found between the ranch and the feedlot levels. Prices paid for feeder cattle did not reflect their future value as slaughter animals. An inherent biological problem in the beef sector is the length of the production process, and the built in delays from the beginning of production to finish. A review of literature from earlier cattle cycles suggests the price distortions were a much bigger problem in the $50 \mathrm{~s}, 60 \mathrm{~s}$ and $70 \mathrm{~s}$, than currently. This indicates that producers are probably incorporating greater levels of information from future markets, than producers in previous cattle cycles. This would suggest that if improvements can be made at other levels of the supply chain, the effects of cycles can be dampened in the future.

The problems at the retail level are of concern, because of the increasing concentration at retail level. Price performance was much greater before the present concentration levels at retail. Given the increased concentration at the packer level, vigilance of suspicious behavior and poor price performance will be an absolute necessity. Retailer and packer processors continue to gain more economic power through consolidation, the use of captive supplies, and increased value added as more and more product moves as case ready into the retail and other consumption chan- 
nels. Producers further out in the supply chain such as feedlot operators, and even further out cow-calf operators, are extremely vulnerable to a break down in the price system. Small distortions at the retail and packer level can result in whip like distortions at the price taker level. In past cattle cycles, poor price performance at the ranch and feedlot levels was probably the cause of exaggerated cattle cycles. Today the poor price potential seems to lie at the retail end of the supply chain.

\section{Bibliography}

1. Anderson, John D. and James N. Trapp. "Estimated Value of Non Price Vertical Coordination in the Fed Cattle Market." Research Institute on Livestock Pricing, Oklahoma State University, February 1999.

2. $\quad$ Anonymous. "Red Meat Yearbook." Economic Research Service. http://USDA.MannLib.cornell.edu/datasets/livestock/94006/.

3. - ---. "The Cattleman's Legal Fund.” Web Page: www.NoBull.net/legal.

4. - --. Bureau of Labor Statistics. http://www.@stats.bls.gov/datahome.htm.

5. ---. Bureau of Economic Analysis, U.S. Dept. of Commerce. http://www.bea.doc.gov/bea/regional/data.

6. Arzac, E.R., and M. Wilkinson. "A Quarterly Econometric Model of United States Livestock and Feed Grains Markets and Some Policy Implications.” American Journal of Agricultural Economics, 61:297-308, 1979.

7. Breiymer, Harold F. Economics of the Products Markets of Agriculture. Ames, IA: Iowa State University Press, 1976.

8. Crom, R.J. "The Cattle Cycle - Looking to the 80's." ESS Staff Report No. Agress. 810105. U.S. Department of Agriculture, Economics and Statistical Service, January 1981.

9. Guebert, Allen. "Maybe It's Just Coincidence." Aberdeen American News, Knight Ridder, November 2000.

10. Hahn, W.F. "Price Transmission Asymmetry in Pork and Beef Markets." Journal of Agricultural Economics Research, 42:21-30. 1990.

11. Hunnicutt, Lynn and Quinn Weninger. "Testing for Market Power in Beef Parking: Where Are We and What's Next?" Research Bulletin 7-99, Agricultural and Applied Economics, Virginia Tech, August 1999.

12. Mathews, Jr., Kenneth H. et al. U.S. Beef Industry, Cattle Cycles, Price Spreads, and Packer Concentration." Economic Research Service Report, TB 1874 USDA, 1999.

13. Mighell, R.L. and L.A. Jones. "Vertical Coordination in Agriculture." USDA, ERS, Agricultural Economics Report No. 19, 1963.

14. Paul, A.B. "The Role of Competitive Market Institutions." Agricultural Economic Research, Vol. 26, 1974.

15. Purcell, Wayne D. "An Approach to Research on Vertical Coordination: The Beef System in Oklahoma." American Journal of Agricultural Economics, Vol. 55, 1973.

16. ---. "A Primer on Beef Demand," Internet: Research Institute on Livestock Pricing. (http://www.AAEA.VT.Edu/rilpl), March 1996.

17. ---. "Measures of Changes in Demand for Beef, Pork, and Chicken, 1975-1998." Research Institute on Livestock Pricing, Agricultural and Applied Economics Department, Virginia Technical University, 1999.

18. ---. Editor. "Price Discovery in Concentrated Livestock Markets: Issues, Answers, Future Directions." Research Institute on Livestock Pricing, Department of Agricultural and Applied Economics, Virginia Tech, February 1997.

19. Trierweiler, John E. and James B. Hassler. "Orderly Production and Marketing in the Beef-Pork Sector," Research Bulletin \#240. University of Nebraska Experiment Station, November 1970.

20. ---."Measuring Efficiency in the Beef-Pork Sector by Price Analysis." Agricultural Economics Research, Vol. 23, Nov. 1, January 1971.

21. ---. "Systems Dynamics: Simulation Modeling for Complex Issues, with Application from the Beef Industry." International Atlantic Economic Conference, Charleston, SC, October 2000.

22. --- "Measuring Efficiency in The Value Structure of The Beef Industry Using Price Analysis", 2001 International Applied Business Research Conference Proceedings, Cancun, Mexico, March 2001. 
23. Ward, C.E. "Short-Period Pricing Models For Fed Cattle and Impacts of Wholesale Carcass Beef and Live Cattle Futures Market Prices." Southern Journal of Agricultural Economics, Vol. 13, 1981.

24. ---. "Comparative Analysis of Cattle Slaughtering and Fabrication Costs." Agribusiness: An International Journal, Vol. 9, 1993.

25. ---. S.R. Koontz, and T.C. Schroeder. "Short-run Captive Supply Relationships with Fed Cattle Transaction Prices." USDA, GIPSA-RR96-3, May 1996.

26. --- D.M. Feuz, and T.C. Schroeder. "Formula Pricing and Grid Pricing Fed Cattle: Implications for Price Discovery and Variability," Research Bulletin 1-99. Research Institute on Livestock Pricing, Agricultural and Applied Economics, Virginia Tech, January 1999.

\section{Endnotes}

${ }^{\mathrm{i}}$ In the formula pricing and grid pricing of fed cattle, where the transaction price is established a transaction price using a formula that includes some other price as a reference. Such prices are not discovered on each transaction. Rather, some other price is used, a price discovered external to the particular formula price transaction. A common base price used, is the box beef price or wholesale price. If this is the base price used in the formula it should be a price that accurately reflects the consumer value established at the retail level. Further, it should be a price that is free of the suspicion of manipulation by concentrated packers and retailers.

Notes 